\title{
Contributions to the cave millipede fauna of the Crimean Peninsula (Diplopoda), with the description of a new species
}

\section{К пещерным двупарноногим многоножккам фауны Крымского полуострова (Diplopoda) с описанием нового вида}

\author{
Sergei I. Golovatch ${ }^{1}$, Ilya S. Turbanov ${ }^{2}$, Didier VandenSpiegel ${ }^{3}$ \\ С.И. Головач ${ }^{1}$, И.С. Турбанов ${ }^{2}$ А. ВанденШпигель ${ }^{3}$
}

\footnotetext{
${ }^{1}$ Institute for Problems of Ecology and Evolution, Russian Academy of Sciences, Leninsky prosp., 33, Moscow, 119071 Russia. E-mail: sgolovatch@yandex.ru

${ }^{1}$ Институт проблем экологии и эволюции РАН, Ленинский пр. 33, Москва 119071, Россия.

${ }^{2}$ Institute of the Biology of Inland Waters, Russian Academy of Sciences, Borok, Yaroslavl Region, 152742 Russia. E-mail: turba13@mail.ru

2 Институт биологии внутренних вод РАН, пос. Борок, Ярославская обл., 152742, Россия.

${ }^{3}$ Musée Royal de 1'Afrique centrale, Tervuren, Belgium. E-mail: didier.van.den.spiegel@africamuseum.be
}

KEY WORDS. Diplopoda, Caucasodesmus, new species, Amblyiulus kovali, variation, taxonomy, cave, fauna, Crimea.

КЛЮЧЕВЫЕ СЛОВА. Diplopoda, Caucasodesmus, новый вид, Amblyiulus kovali, изменчивость, таксономия, пещера, фауна, Крым.

ABSTRACT. A new presumed troglobiont millipede is described from a cave in the Crimea: $\mathrm{Cauca}$ sodesmus birsteini sp.n. New data on the variability and distribution of Amblyiulus kovali Golovatch, 2008, another endemic Crimean cavernicole, are presented. At present, the diplopod fauna of the Crimea comprises 18 species, 12 genera, eight families and six orders, among which at least five species are presumed endemic troglobionts and their distributions are mapped.

РЕЗЮМЕ. Из пещеры в Крыму описан новый, предположительно троглобионтный вид диплопод Caucasodesmus birsteini sp.n. Представлены новые данные по изменчивости и распространению Amblyiulus kovali Golovatch, 2008, еще одного эндемичного крымского пещерного вида. В настоящее время диплоподы фауны Крыма включают 18 видов, 12 родов, восемь семейств и шесть отрядов, среди которых по меньшей мере пять видов - вероятные эндемичные троглобионты, и их ареалы представлены на карте.

The millipede fauna of the Crimea, Russia, a prominent peninsula in the Black Sea, has hitherto been known to comprise only 17 species from 12 genera, eight families and six orders [Golovatch 2008, 2011; Golovatch, VandenSpiegel, 2015; Short, 2015; Turbanov et al., 2016]. At least five of the species seem to be endemic to the Crimea, while most of that generally depauperate fauna show vast (Euro-)Mediterranean distributions, including several presumed anthropochores [Golovatch, 2008]

Most of the recent progress in studies on Crimean diplopods has been due to cave fauna. In addition to at least two troglophiles, as many as five millipede species appear to be presumed troglobionts, representing two genera in two families and orders: Caucasodesmus Golovatch, 1985 (Trichopolydesmidae, Polydesmida) and Amblyiulus Silvestri, 1896 (Julidae, Julida) [Turbanov et al., 2016]. The present paper provides the description of still another new troglobiont Caucasodesmus from the Crimea. It also gives new records of and morphological variations in the sole Crimean julid troglobiont, as well as an updated checklist of the Crimean millipedes.

\section{Material and methods}

Material serving as the basis for the present contribution was collected by the second author in several caves located in different karsts in the Crimea. All material is donated to the Zoological Museum, State University of Moscow (ZMUM + entry number), Russia. The samples are stored in 70-75\% ethanol. Specimens for scanning electron microscopy (SEM) were air-dried, mounted on aluminium stubs, coated with gold and studied using a JEOL JSM-6480LV scanning electron microscope, all performed at Tervuren, Belgium. The colour picture was taken in Moscow with a Canon EOS 5D digital camera and stacked using Zerene Stacker software.

\section{Taxonomic part}

Caucasodesmus birsteini sp.n. Figs 1-2.

HOLOTYPE $\sigma^{7}$ (ZMUM 03552 ), Crimean Peninsula, TshatyrDagh Karst Massif, Mramornaya Cave, 2.II.2016, leg. I. Turbanov. 

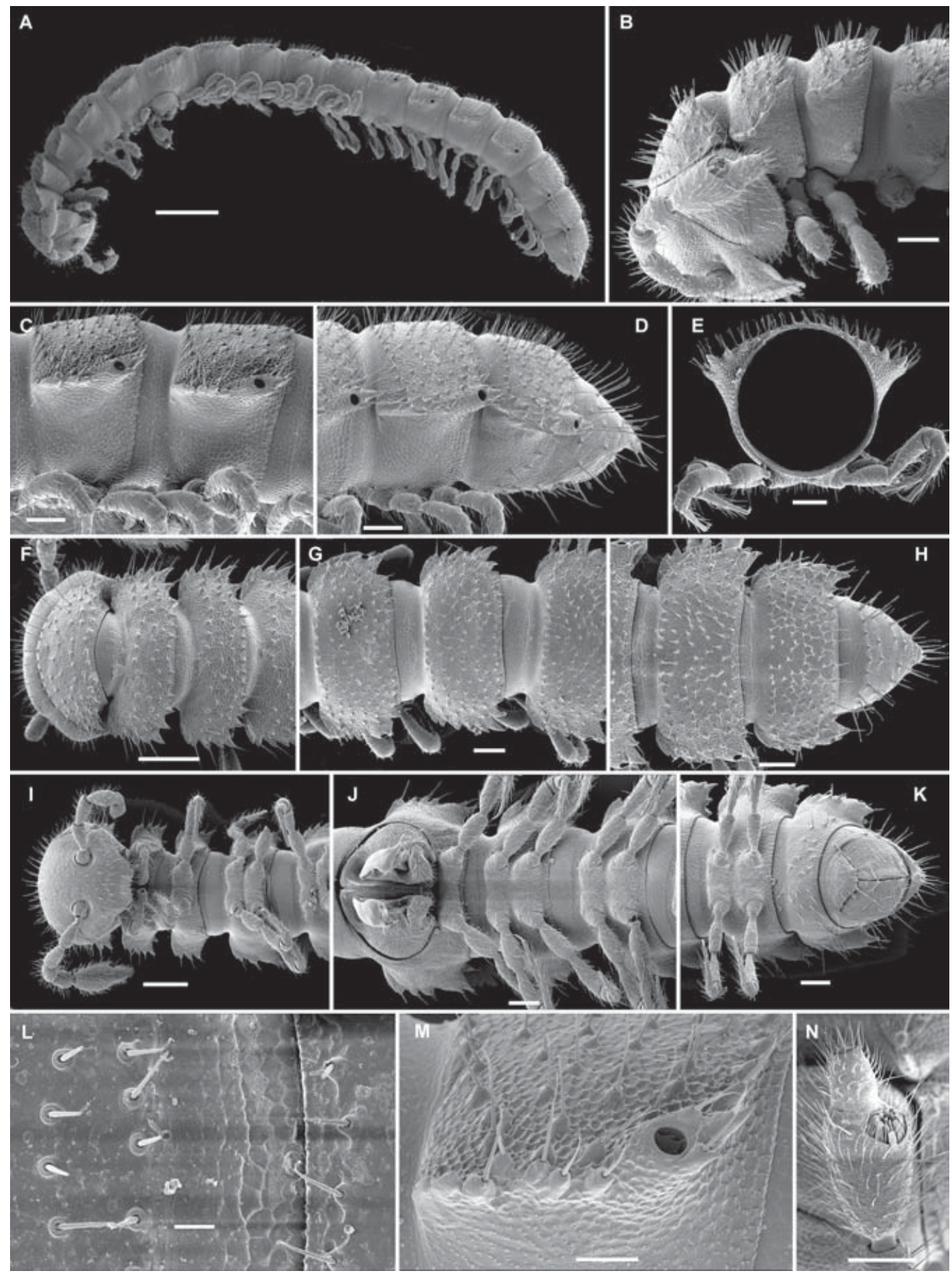

Fig. 1. Caucasodesmus birsteini sp.n., O paratype, SEM micrographs: A - habitus, lateral view; B, F, I - anterior part of body, lateral, dorsal and ventral views, respectively; $\mathrm{C}, \mathrm{G}, \mathrm{J}$ - midbody segments, lateral, dorsal and ventral views, respectively; D, H, K posterior part of body, lateral, dorsal and ventral views, respectively; E - cross-section of a midbody segment, caudal view; L - tergal setae and structure of adjacent surface of metaterga and prozona, dorsal view; $\mathrm{M}$ - midbody poriferous metatergum, lateral view; $\mathrm{N}$ antennomeres 6-8, dorsal view. Scale bars: 0.5 (A), 0.2 (B, F, K), 0.1 (C-E, G, H, N), 0.05 (M) and $0.02 \mathrm{~mm}(\mathrm{~L})$.

Рис. 1. Caucasodesmus birsteini sp.n., паратип О7, SЕМ-микрографии: А - общий вид, сбоку; В, F, I - передняя часть тела, соответственно сбоку, сверху и снизу; C, G, J - среднетуловищные сегменты, соответственно сбоку, сверху и снизу; D, H, K задняя часть тела, соответственно сбоку, сверху и снизу; Е - поперечный разрез через среднетуловищный сегмент, сзади; L тергальные шетинки и структура прилежащей поверхности метатергита и прозонита, сверху; $\mathrm{M}$ - среднетуловищный несущий пору метатергит, сбоку; N — членики 6-8-го усика, сверху. Масштаб: 0,5 (A), 0,2 (B, F, K), 0,1 (C-E, G, H, N), 0,05 (M) и 0,02 мм (L). 

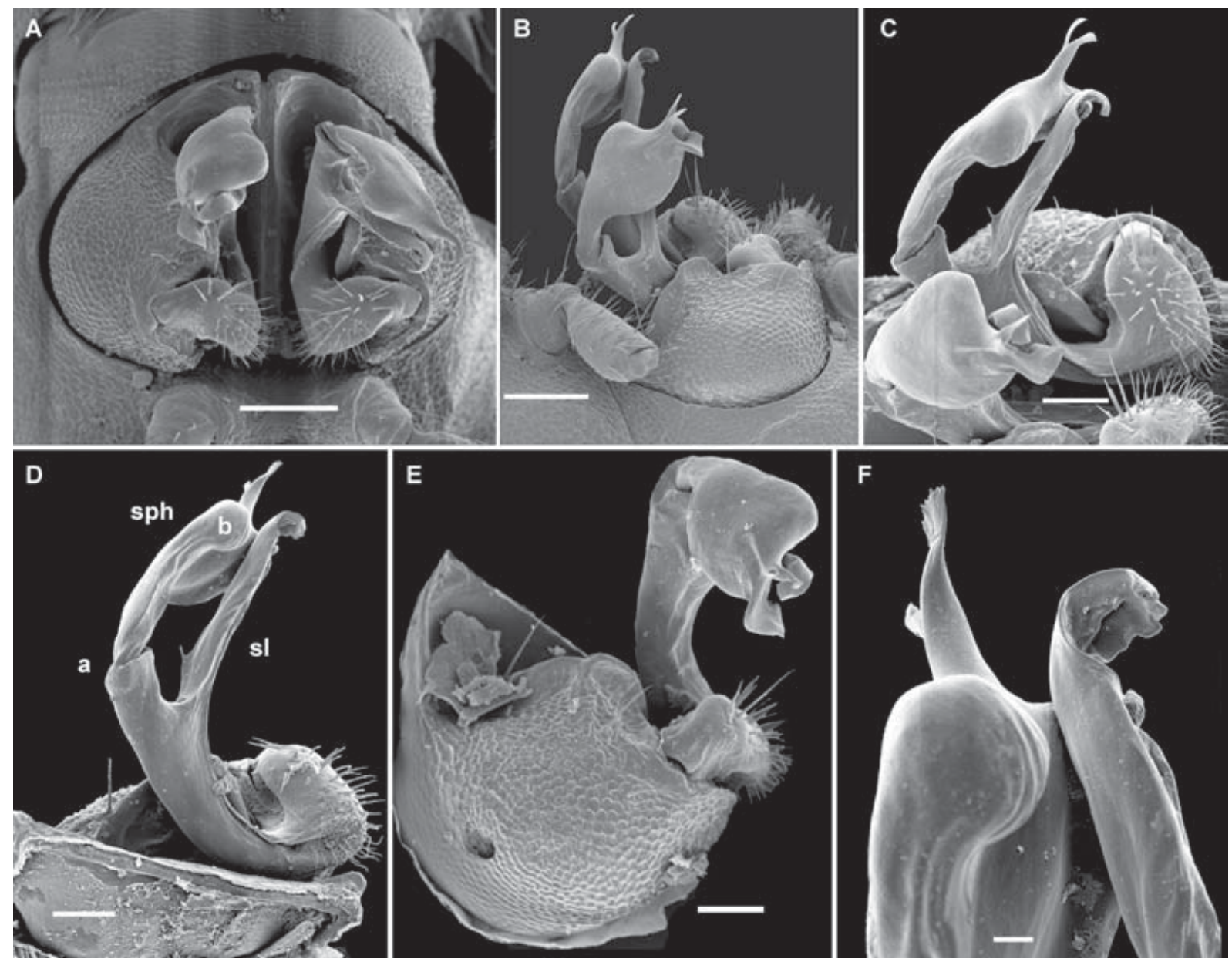

Fig. 2. Caucasodesmus birsteini sp.n., $\mathrm{O}^{7}$ paratype, SEM micrographs, gonopods: A-C - both gonopods in situ, ventral, lateral and ventrolateral views, respectively; D - left gonopod, mesal view; E — right gonopod, lateral view; F — distal part of left gonopod, ventromesal view. Scale bars: 0.1 (A, B, D), 0.05 (C, E) and $0.01 \mathrm{~mm}(\mathrm{~F})$.

Рис. 2. Caucasodesmus birsteini sp.n., паратип O7, SEM-микрографии, гоноподы: А-C - оба гонопода на месте, соответственно снизу, сбоку и одновременно снизу и сбоку; D - левый гонопод, изнутри; Е — правый гонопод, сбоку; F — дистальная часть левого гонопода, одновременно снизу и изнутри. Масштаб: 0,1 (A, B, D), 0,05 (C, Е) и 0,01 мм (F).

PARATYPES: $140^{\top} \sigma^{\top}, 10$ ㅇ, 1 subadult + (ZMUM $\left.\rho 3553\right)$ $1 O^{7}$ (SEM, ZMUM 03554$)$ ), same data, together with holotype.

NAME. Honours Y.A. Birstein, one of the pioneer students of cave fauna in the former Soviet Union.

DIAGNOSIS. Differs primarily by a trifid solenophore which is conspicuously bulged at about midway, and a particularly slender solenomere (Fig. 2).

DESCRIPTION. Length of adults ca 7-8 $\mathrm{mm}$, width of midbody pro- and metazonae 0.5 and $0.7-0.8 \mathrm{~mm}$ $\left(\sigma^{\gamma},+\right)$, respectively. Holotype ca $7 \mathrm{~mm}$ long, 0.5 and $0.8 \mathrm{~mm}$ wide on midbody pro- and metazonae, respectively. Coloration entirely pallid, only sometimes very faintly pinkish.

Body with 19 segments. Tegument mainly dull, at most slightly shining, texture very delicately alveolate and scaly. Head densely pilose throughout; epicranial suture distinct, but thin; isthmus between antennae ca 2 times broader than diameter of antennal socket (Fig. 1I). Antennae rather short, evidently clavate due to a considerably enlarged antennomere 6 , slightly over- reaching segment 2 dorsally; antennomeres 2, 3 and 6 longest, subequal in length (Fig. 1I); only antennomere 6 with a large, compact, roundish, distodorsal group of bacilliform sensilla (Fig. 1N). Genae squarish, gnathochilarium without peculiarities.

In width, collum $<$ segment $2=3<$ head $=4<5=16$ $\left(\sigma^{7}\right)$, or head $=$ collum $=$ segment $2=4<5=16(+)$, thereafter body gradually tapering towards telson. Paraterga moderately developed (Fig. 1E), starting from collum, subhorizontal to slightly declivous, set high, but always lying slightly below a faintly convex dorsum, devoid of shoulders frontally (Figs $1 \mathrm{~F}-\mathrm{H}$ ). Caudal corner of collum and postcollum paraterga invariably spiniform, pointed, increasingly clearly extending behind rear tergal margin. Lateral edge of paraterga with neither a marginal groove nor a callus, mostly with 5-6, very clear, setigerous indentations (Fig. 1M). Pore formula normal, ozopores evident, round, located laterally in front of caudalmost incision. Collum and following metaterga beset with numerous, rather irreg- 


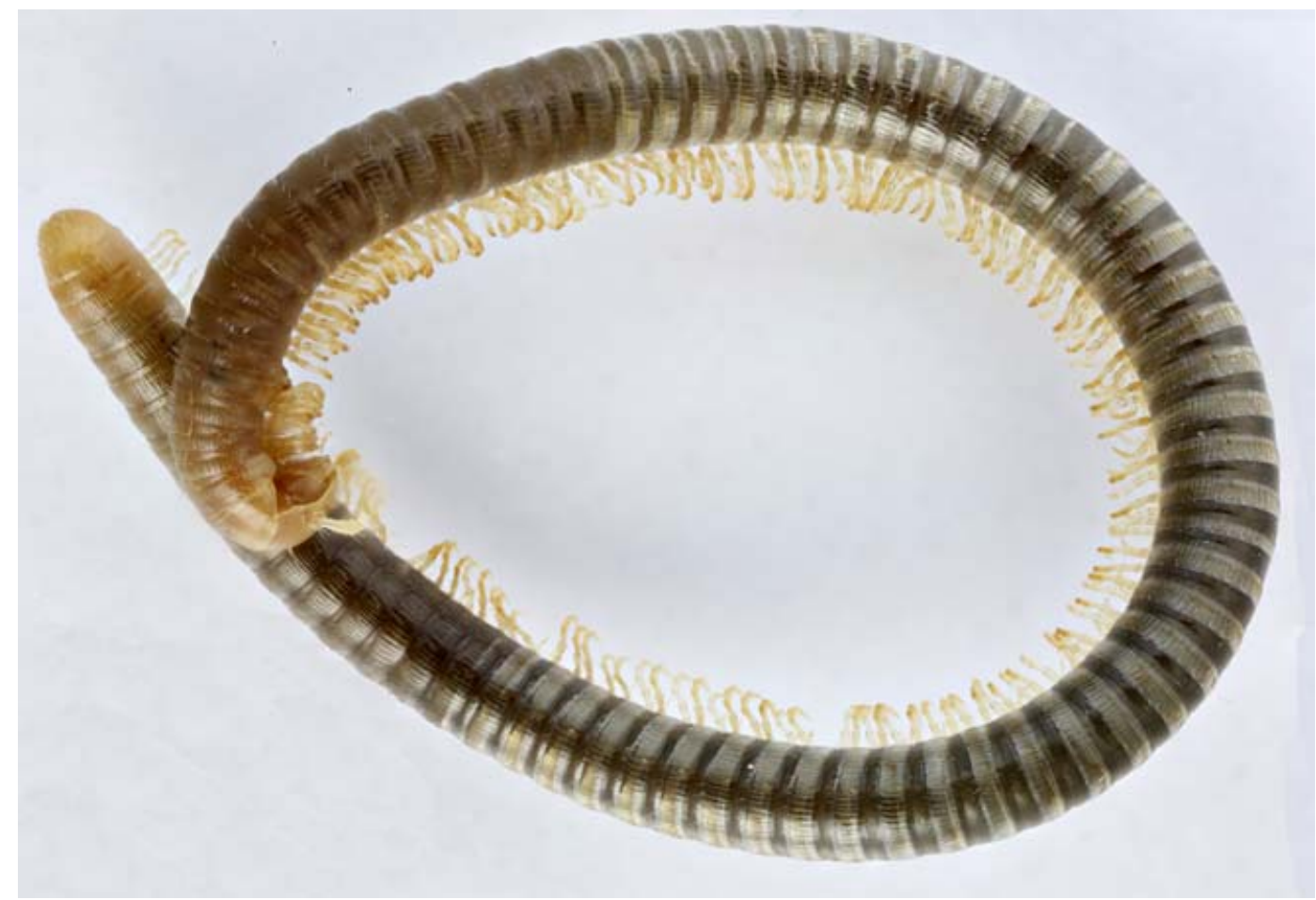

Fig. 3. Habitus of Amblyiulus kovali Golovatch, 2008, $0^{\text {T }}$ from Avantyura Cave. Picture by K.V. Makarov (Moscow, Russia), taken not to scale.

Рис. 3. Общий вид Amblyiulus kovali Golovatch, 2008, О7 из пещеры Авантюра. Фотография К.В. Макарова, снято без масштаба.

ular, medium-sized setae borne on minute knobs, these knobs growing a little more prominent in caudalmost rows; polygonal bosses missing (Figs 1F-H, L, M). Stricture between pro- and metazonae wide, shallow and smooth. Limbus very thin, very faintly microdenticulate, nearly smooth (Figs 1L, M). Pleurosternal carinae absent. Epiproct short, conical, directed caudoventrally; pre-apical papillae small (Figs 1A, D, H, K). Hypoproct trapeziform, setiferous papillae at caudal corners small, but evident, rather well separated (Fig. $1 \mathrm{~K})$.

Sterna broad, without modifications, poorly setose (Fig. 1I-K). Epigynal ridge very low. Legs rather short and stout (Figs 1E, J), ca 1.2-1.3 $\left(\mathrm{O}^{7}\right)$ or $0.9-1.0(+)$ times as long as midbody height; + legs slightly slenderer; $O^{7}$ legs with clearly enlarged and micropapillate prefemora and femora; tarsi especially long and slender, claw long, ca 1/4 length of tarsus; sphaerotrichomes missing. Gonapophyses on $\sigma^{7}$ coxae 2 vestigial, lamellar, cup-shaped.

Gonopod aperture subcordiform, broader than $\sigma^{7}$ prozona 7 (Fig. 1J). Gonopods (Figs 1J, 2) rather complex, coxae large, subglobose, micropapillate and setose laterally, totally devoid of cannulae; telopodites quite deeply sunken into a rather prominent gonocoel, only apical parts being moderately exposed; each telopodite deeply biramous, strongly curved caudad; prefemoral (= densely setose) parts short and held subtransversely to main body axis, but acropodites lying subparallel to each other; telopodite consisting of a shorter, mesal, rather loose, slender, tubiform solenomere (sl) (= endomere) and a somewhat longer, lateral, slightly sigmoid, apically trifid solenophore (sph), or exomere, with a conspicuous round bulge (b) at about midway; sl starting with a typical hole for a cannula to hinge into, but ending up by a small lamellar cup with orifice of seminal groove lying at cup bottom; sph with a remarkable articulation (a) near base.

REMARKS. Using the latest key to Caucasodesmus spp. [Golovatch, VandenSpiegel, 2015], the new species keys out to $C$. tauricus Golovatch, 2011, but differs from it and other congeners primarily by the shape of the gonopodal telopodite (see Diagnosis above).

Interestingly, among all four presently known Crimean species of Caucasodesmus, each is confined to caves in its own karst or part of a karst. Thus, C. turbanovi Golovatch et VandenSpiegel, 2015 occurs solely in the Karabi Karst Massif, both C. svetlanae Golovatch et VandenSpiegel, 2015 and C. tauricus, although inhabiting different caves in the same, largest Ai-Petri Karst Massif, are restricted to its south- and northwestern parts, respectively, whereas $C$. birsteini sp.n. populates a cave in the Tshatyr-Dagh Karst Massif (cf. Golovatch, VandenSpiegel, 2015]. Allopatry is thus manifest (Map). 


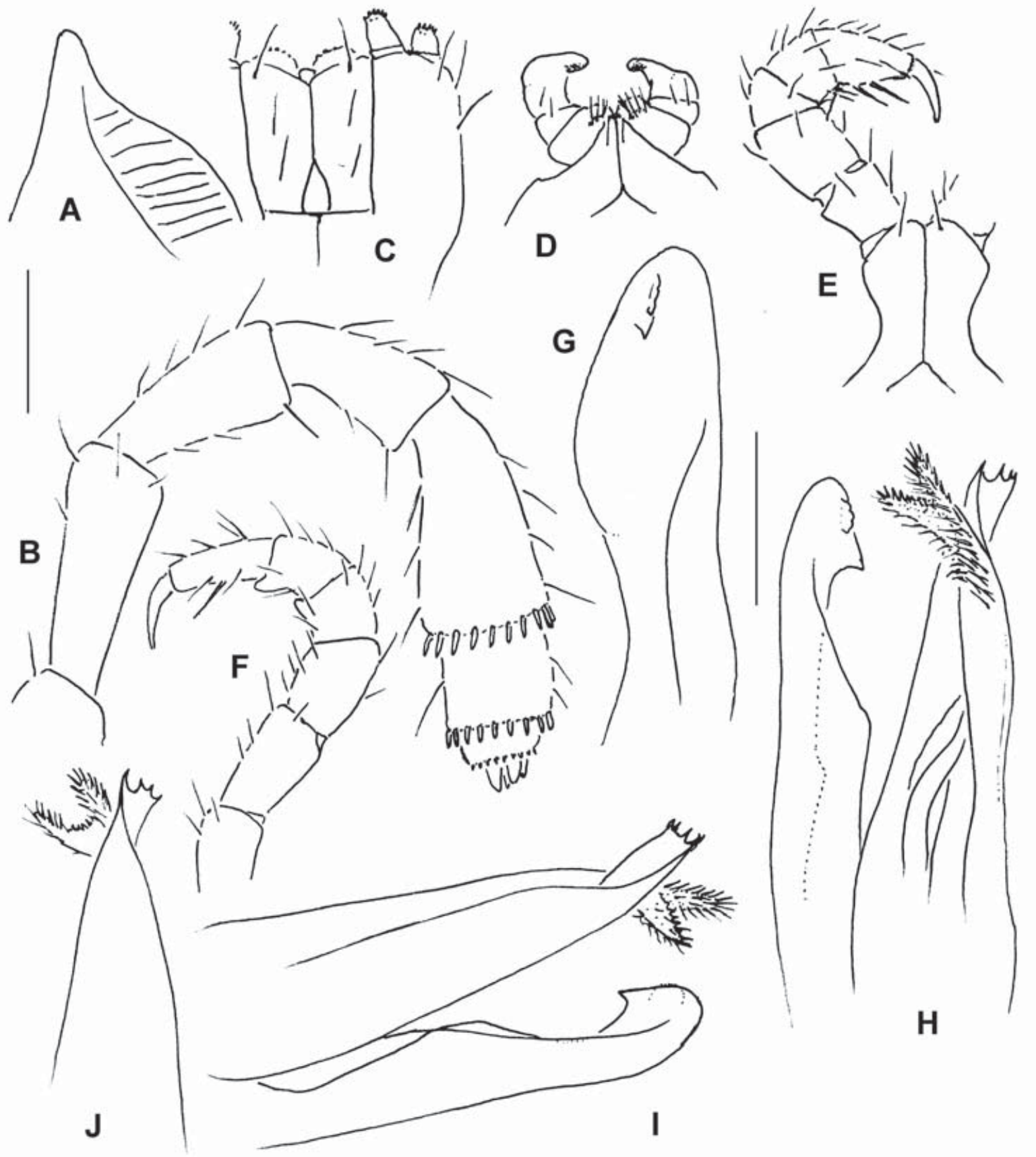

Fig. 4. Amblyiulus kovali Golovatch, 2008, $0^{7}$ from Avantyura Cave. A - ventral lobe on segment 7, lateral view; B - antenna, lateral view; C - gnathochilarium, ventral view; D - leg 1, oral view; E — leg 2, oral view; F - leg of a midbody segment, oral view; $\mathrm{G}$ - promere, caudal view; H, I - right half of both gonopods, lateral and mesal views, respectively; J - distal part of left opisthomere, submesal view. Scale bars $0.2 \mathrm{~mm}$.

Рис. 4. Amblyiulus kovali Golovatch, 2008, О7 из пещеры Авантюра. А - брюшная лопасть на сегменте 7, сбоку; В - усик, сбоку; С — гнатохилярий, снизу; D - нога 1, спереди; Е - нога 2, спереди; F — нога среднетуловищного сегмента, спереди; G промер, сзади; Н, I - правая половина обоих гоноподов, соответственно сбоку и изнутри; J - дистальная часть опистомера, почти изнутри. Масштаб 0,2 мм.

Amblyiulus kovali Golovatch, 2008

Figs 3-5.

Amblyiulus kovali Golovatch, 2008: 103 (original description). Amblyiulus kovali - Golovatch, VandenSpiegel, 2015: 1 (mere mention); Turbanov et al., 2016: 1291, fig. 8 (record and picture).
MATERIAL. $10 \sigma^{\top} \sigma^{\top}, 9$ oᄋ, 1 juv. (ZMUM 03555$), 1 \sigma^{\top}$ (SEM), Crimean Peninsula, Ai-Petri Yaila Karst Massif, Druzhba Cave, 4.V.2016; 1 O (ZMUM 03556 ), same massif, Bash Dere area, Avantyura Cave, 15.XI.2014; 1 o (ZMUM 03557), same massif, Baydarskaya Valley, Skelskaya Cave, 1.VII.2010; $2 \bigcirc^{\top} \sigma^{\top}, 1$

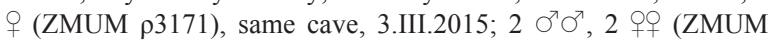



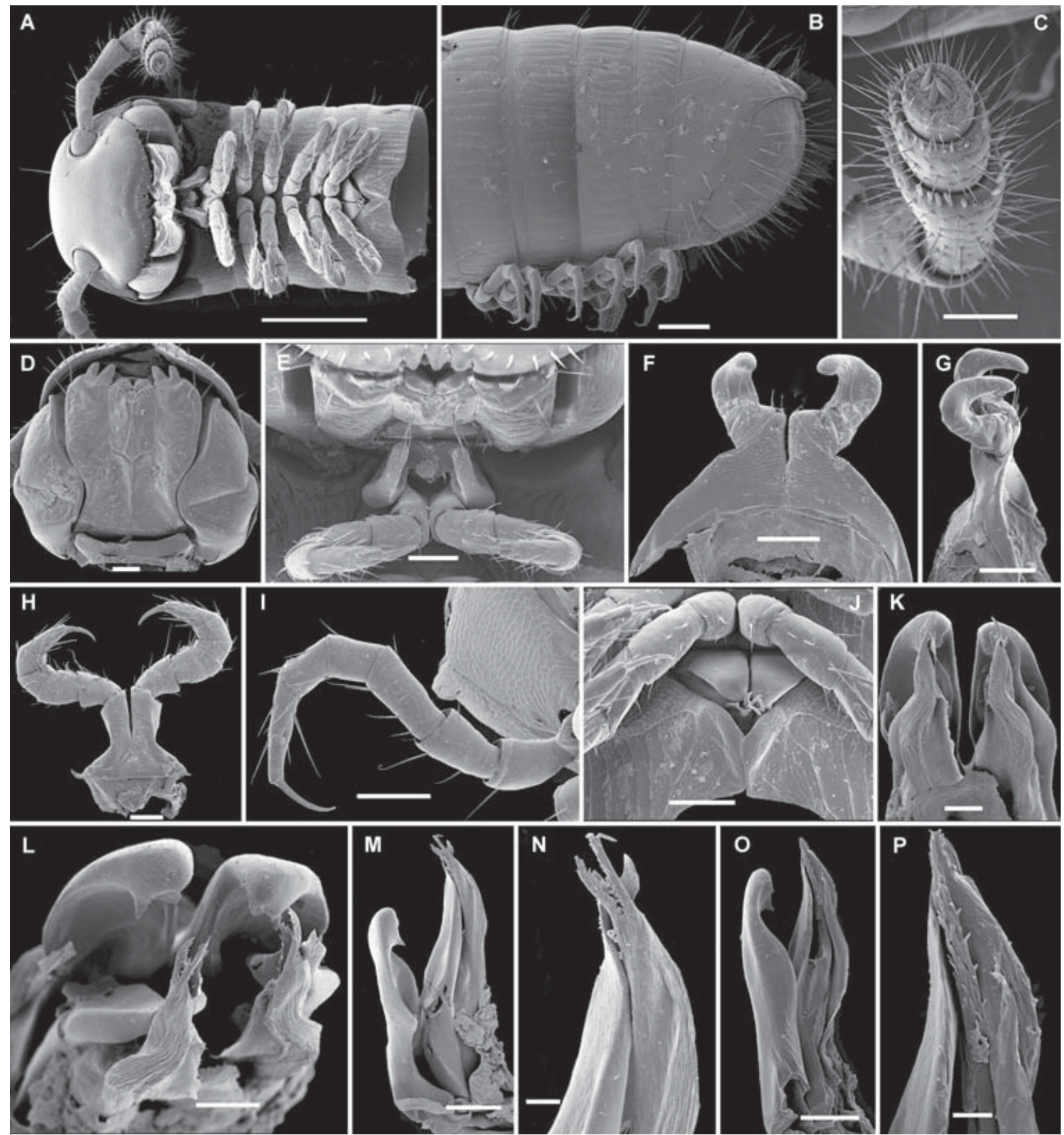

Fig. 5. Amblyiulus kovali Golovatch, 2008, $0^{7}$ from Druzhba Cave, SEM micrographs. A - anterior part of body, ventral view; B caudal part of body, lateral view; C — distal antennomeres, dorsofrontal view; D — head, ventral view; E — labrum, gnathochilarium, legs 1 and 2, ventral view; F, G - leg-pair 1, oral and sublateral views, respectively; H - leg-pair 2 and penes, caudal view; I - leg of a midbody segment, caudal view; J - legs 7 and ventral side of segment 7, ventral view; K, L — gonopodal block, caudal and ventrocaudal views, respectively; $\mathrm{M}, \mathrm{O}$ - right half of both gonopods, mesal and submesal views, respectively; $\mathrm{N}, \mathrm{P}$ - distal part of right opisthomere, mesal and caudomesal views, respectively. Scale bars: $0.5(\mathrm{~A}), 0.2(\mathrm{~B}), 0.1(\mathrm{C}-\mathrm{J}, \mathrm{M}-\mathrm{O})$ and $0.05 \mathrm{~mm}(\mathrm{~K}, \mathrm{~L})$.

Рис. 5. Amblyiulus kovali Golovatch, 2008, О७ из пещеры Дружба, SEM-микрографии. А - передняя часть тела, снизу; В задняя часть тела, сбоку; C - дистальные членики усика, одновременно сверху и спереди; D — голова, снизу; Е — верхняя губа, гнатохилярий, ноги 1 и 2, снизу; F, G - 1-я пара ног, соответственно спереди и почти сбоку; H - 2-я пара ног и пенисы, сзади; I - нога среднетуловищного сегмента, сзади; J - ноги 7 и брюшная сторона 7-го сегмента, снизу; K, L — блок гоноподов, соответственно сзади и одновременно снизу и сзади; М, О - правая половина гоноподов, соответственно изнутри и почти изнутри; $\mathrm{N}, \mathrm{P}$ - дистальная часть правого опистомера, соответственно изнутри м одновременно сзади и изнутри. Масштаб: 0,5 (A), 0,2 (B), 0,1 (C-J, M-O) и 0,05 мм (K, L). 


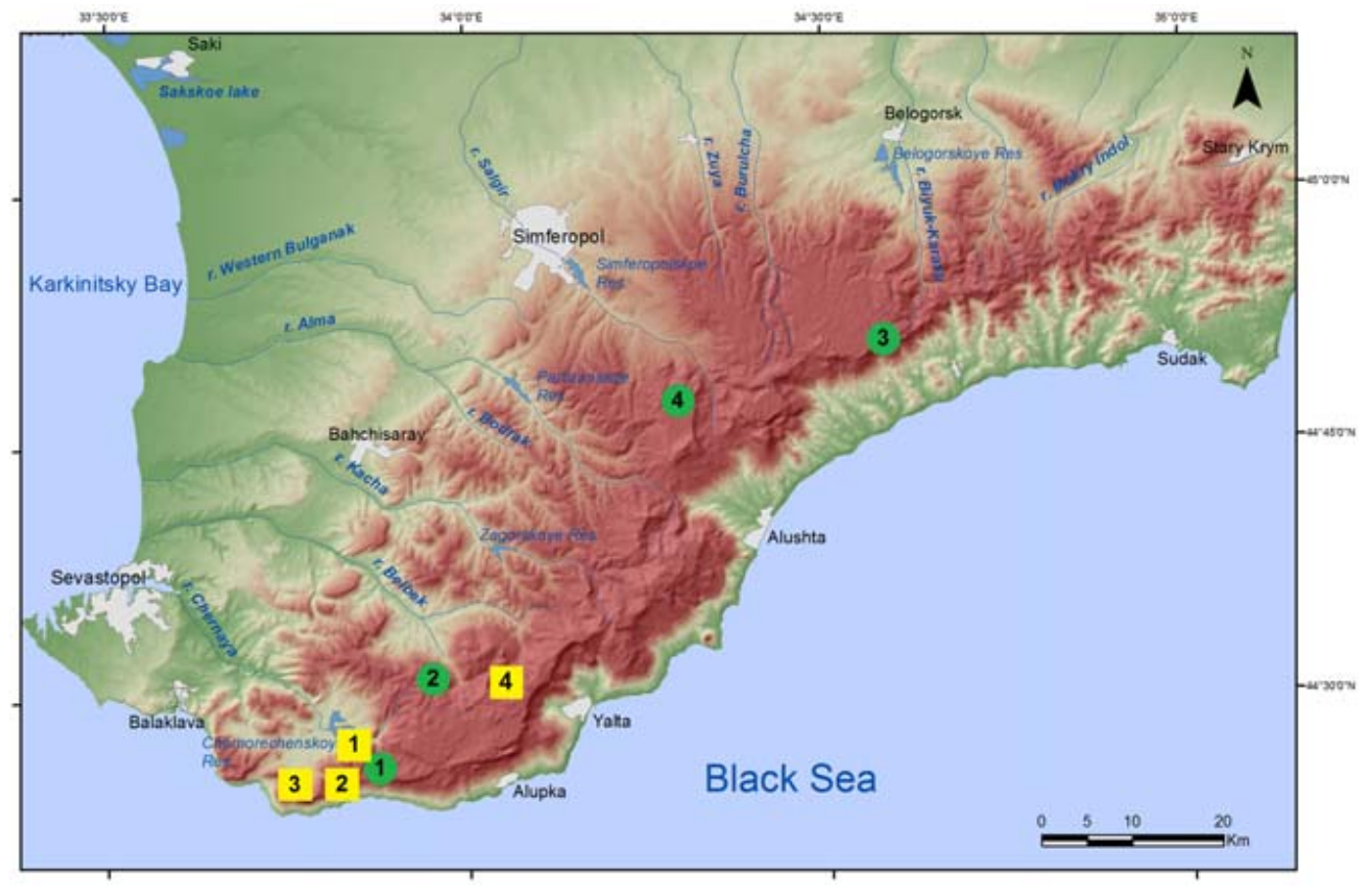

Map. Distribution of the known endemic troglobiont millipede species in the Crimean Peninsula. The genus Caucasodesmus (green circle): $1-$ C. svetlanae (Kuznetsova Cave), $2-$ C. tauricus (Villyaburunskaya Cave), $3-$ C. turbanovi (Tuakskaya Cave), $4-\mathrm{C}$. birsteini sp.n. (Mramornaya Cave). Amblyiulus kovali (yellow square): 1 - Skelskaya Cave, 2 - Druzhba Cave, 3 - Mamut-Tshokrak Cave, 4 - Avantyura Cave.

Карта. Распространение известных эндемичных троглобионтных видов многоножек-диплопод на Крымском полуострове. Род Caucasodesmus (зеленый круг): $1-$ C. svetlanae (пещера Кузнецова), $2-$ C. tauricus (пещера Виллябурунская), $3-C$. turbanovi (пещера Туакская), 4 - C. birsteini sp.n. (пещера Мраморная). Вид Amblyiulus kovali (желтый квадрат): 1 - пещера Скельская, 2 - пещера Дружба, 3 - пещера Мамут-Чокрак, 4 - пещера Авантюра.

९3558), same massif, Baydarskaya Valley, Mamut-Tshokrak Cave, 21.VII.2010; 1 ㅇ (ZMUM 03559), same cave, 26.VII.2010; 1 O

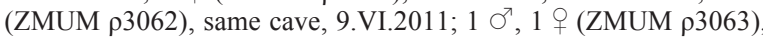
same cave, 2.VI.2013, all leg. I. Turbanov.

REMARKS. This likely troglobiont species, originally described from Skelskaya Cave [Golovatch, 2008], appears to populate several caves, all within the AiPetri Karst Massif (Map).

Table 1 shows variations in body size and the number of body segments both in types and some of the new samples, while new illustrations (Figs 3-5) are provided not only to document the species' identity, but also to demonstrate slight variations in several other characters, including gonopodal ones. The body is always unpigmented, from pallid to light yellowish, light grey or light brown, in vivo often with reddish repugnatorial glands visible through a translucent tegument. Sole pads on $\sigma^{7}$ postfemora and tibiae are small, but usually evident (Fig. 4F), only sometimes absent (Fig. 5I). Because the body is slightly compressed and the height/width ratio is invariably 1:0.9, only the height of midbody segments is considered in the measurements data below. The measurements are given in millimeters and concern only complete, non-fragmented adults. The segment formula refers to the number of podous segments, conventionally including also the collum (p), followed by the number of apodous ones (a), plus telson (T).
Despite the variations, sometimes quite profound both in body length and segment counts, only a single species seems to be involved. Thus, A. kovali is the sole representative of Amblyiulus in the Crimea, whereas in the adjacent Caucasus only epigean, partly possibly geobiont congeners are known to occur. Several julid genera inhabit numerous caves in the western Caucasus within Russia, Abkhazia and Georgia, but there is no Amblyiulus among such [Turbanov et al., 2016].

Bar-coding research in the genetic variation of individual populations of $A$. kovali could clarify this picture, but no such information is available yet.

\section{Conclusions}

At present, the diplopod fauna of the Crimea comprises 18 species from 12 genera, eight families and six orders. It can be summarized as follows (Table 2), containing a few taxonomic updates compared to the latest checklist [Golovatch, 2008].

Map shows the distribution of all five endemic troglobiont millipedes known to occur in the Crimean Peninsula.

ACKNOWLEDGEMENTS. We are most grateful to Kirill Makarov (Moscow, Russia) who took the colour picture, 
Table 1. Variations in body size and the number of body segments in Amblyiulus kovali.

Таблица 1. Изменчивость размера тела и числа сегментов тела у Amblyiulus kovali.

\begin{tabular}{|c|c|c|c|c|c|c|c|c|c|}
\hline $\begin{array}{l}\text { Locality and } \\
\text { status }\end{array}$ & Sex & $\begin{array}{l}\text { Body } \\
\text { length }\end{array}$ & $\begin{array}{l}\text { Body } \\
\text { height }\end{array}$ & $\begin{array}{l}\text { Segment } \\
\text { formula }\end{array}$ & Locality & Sex & $\begin{array}{l}\text { Body } \\
\text { length }\end{array}$ & $\begin{array}{l}\text { Body } \\
\text { height }\end{array}$ & $\begin{array}{l}\begin{array}{l}\text { Segment } \\
\text { formula }\end{array} \\
\end{array}$ \\
\hline Skelskaya Cave & & & & & $\begin{array}{l}\text { Mamut- } \\
\text { Tshokrak Cave }\end{array}$ & $0^{7}$ & 15 & 0.8 & $50 p+3 a+T$ \\
\hline holotype & $0^{2}$ & 22 & 1.0 & $68 p+3 a+T$ & & $0^{7}$ & 15 & 0.7 & $51 p+4 a+T$ \\
\hline paratype & $0^{1}$ & 21 & 1.0 & $65 p+3 a+T$ & & $0^{7}$ & 24 & 1.0 & $67 p+2 a+T$ \\
\hline paratype & $0^{1}$ & 16 & 0.8 & $57 p+2 a+T$ & & कq & 20 & 1.0 & $65 p+4 a+T$ \\
\hline paratype & 우 & 19 & 0.9 & $60 p+4 a+T$ & Druzhba Cave & $0^{7}$ & 22 & 1.0 & $66 p+1 a+T$ \\
\hline topotype & $0^{2}$ & 26 & 1.0 & $77 p+1 a+T$ & & $0^{7}$ & 20 & 0.9 & $63 p+4 a+T$ \\
\hline topotype & $0^{2}$ & 21 & 1.0 & $65 p+2 a+T$ & & $0^{x}$ & 20 & 0.9 & $63 p+3 a+T$ \\
\hline Avantyura Cave & $0^{1}$ & 24 & 1.0 & $76 p+1 a+T$ & & qक & 20 & 1.0 & $62 p+2 a+T$ \\
\hline & & & & & & $0^{2}$ & 21 & 1.0 & $68 p+1 a+T$ \\
\hline
\end{tabular}

Table 2. Fauna and distribution of Diplopoda of the Crimea. Таблица 2. Фауна и распространение многоножек-диплопод Крыма.

\begin{tabular}{|c|c|c|c|c|c|}
\hline Taxa & Distribution pattern & $\begin{array}{c}\text { Steppe } \\
\text { part }\end{array}$ & $\begin{array}{l}\text { Mountainous } \\
\text { forested part }\end{array}$ & Caves & $\begin{array}{l}\text { Anthropoge- } \\
\text { nous habitats }\end{array}$ \\
\hline \multicolumn{6}{|l|}{$\begin{array}{l}\text { Order Polyxenida } \\
\text { Family Polyxenidae }\end{array}$} \\
\hline 1. Polyxenus lagurus (Linnaeus, 1758) & Holarctic & - & + & - & - \\
\hline $\begin{array}{l}\text { Family Lophoproctidae } \\
\text { 2. Lophoproctus coecus Pocock, } 1894\end{array}$ & $\begin{array}{l}\text { Ancient } \\
\text { Mediterranean }\end{array}$ & - & + & - & - \\
\hline \multicolumn{6}{|l|}{$\begin{array}{l}\text { Order Glomerida } \\
\text { Family Glomeridae }\end{array}$} \\
\hline 3. Trachysphaera costata (Waga, 1857) & $\begin{array}{l}\text { E-Euromedi- } \\
\text { terranean }\end{array}$ & - & - & + & - \\
\hline \multicolumn{6}{|l|}{$\begin{array}{l}\text { Order Chordeumatida } \\
\text { Family Anthroleucosomatidae }\end{array}$} \\
\hline 4. ?Anamastigona $\mathrm{sp}$. & $?$ & - & + & - & - \\
\hline \multicolumn{6}{|l|}{$\begin{array}{l}\text { Order Callipodida } \\
\text { Family Schizopetalidae }\end{array}$} \\
\hline 5. Eurygyrus ochraceus C.L. Koch, 1847 & E-Mediterranean & - & - & - & + \\
\hline \multicolumn{6}{|l|}{$\begin{array}{l}\text { Order Polydesmida } \\
\text { Family Polydesmidae }\end{array}$} \\
\hline 6. Brachydesmus jubatus Attems, 1907 & E-Mediterranean & - & + & - & - \\
\hline 7. Polydesmus escherichii Verhoeff, 1896 & E-Mediterranean & - & + & - & - \\
\hline 8. P. mediterraneus Daday, $1889^{1}$ & Mediterranean & - & + & + & - \\
\hline 9. P. stuxbergi Attems, $1907^{2}$ & E-European & + & + & + & + \\
\hline \multicolumn{6}{|l|}{ Family Trichopolydesmidae } \\
\hline 10. Caucasodesmus birsteini sp.n. & Endemic & - & - & + & - \\
\hline $\begin{array}{l}\text { 11. Caucasodesmus svetlanae Golovatch et } \\
\text { VandenSpiegel, } 2015\end{array}$ & Endemic & - & - & + & - \\
\hline 12. Caucasodesmus tauricus Golovatch, 2011 & Endemic & - & - & + & - \\
\hline $\begin{array}{l}\text { 13. Caucasodesmus turbanovi Golovatch et } \\
\text { VandenSpiegel, } 2015\end{array}$ & Endemic & - & - & + & - \\
\hline \multicolumn{6}{|l|}{$\begin{array}{l}\text { Order Julida } \\
\text { Family Julidae }\end{array}$} \\
\hline 14. Amblyiulus kovali Golovatch, 2008 & Endemic & - & - & + & - \\
\hline 15. Cylindroiulus horvathi (Verhoeff, 1897) & $\begin{array}{l}\text { E-Euromedi- } \\
\text { terranean }\end{array}$ & - & + & + & - \\
\hline $\begin{array}{l}\text { 16. Byzantorhopalum rossicum (Timotheew, } \\
\text { 1897) }\end{array}$ & $\begin{array}{l}\text { E-Euromedi- } \\
\text { terranean }\end{array}$ & + & + & - & + \\
\hline 17. Megaphyllum tauricum (Attems, 1907) & Endemic & - & + & + & - \\
\hline 18. Pachyiulus flavipes (C.L. Koch, 1847) & Mediterranean & - & + & + & + \\
\hline
\end{tabular}

${ }^{1}$ This species is quite common across forested parts of the montane Crimea, and both in the Crimea and Caucasus it seems to represent an anthropochore introduction [Golovatch, 2008; Golovatch et al., 2016].

${ }^{2}$ This species has been recorded not only from the Rostov-on-Don Region of Russia, but also in Villyaburunskaya Cave, Crimea [Evsyukov, Golovatch, 2013]. 
as well as to Kirill Mikhailov and Elena Kudryavtseva (ZMUM) who helped us incorporate the material in the collection under their care. Special thanks go to Aleksandr Kozlov, Head of the "Onix-Tour" Speleotourist Centre (Simferopol, Crimea), who kindly made it possible for IT to visit Mramornaya Cave, as well as to Elena Chertoprud (Moscow, Russia) for the help rendered during collecting.

This study was carried out under partial financial support rendered to IT by the Russian Foundation for Basic Research (projects 16-34-00275 мол_а and 17-54-40017 Абх_а).

\section{References}

Evsyukov A.P., Golovatch S.I. 2013. Millipedes (Diplopoda) from the Rostov-on-Don Region, southern Russia // Arthropoda Selecta. Vol.22. No.3. P.207-215.

Golovatch S.I. 2008. On three remarkable millipedes (Diplopoda) from the Crimea, Ukraine // International Journal of Myriapodology. Vol.1. P.97-110. doi.org/10.1163/187525408X316767

Golovatch S.I. 2011. The millipede genus Caucasodesmus Golovatch, 1985, with the description of a new species from the
Crimea, Ukraine (Polydesmida, Diplopoda, Trichopolydesmidae) // ZooKeys. Vol.93. P.1-8. doi.org/10.3897/zookeys. 93.1159

Golovatch S.I., VandenSpiegel D. 2015. Two new species of the millipede genus Caucasodesmus Golovatch, 1985 from the Crimea, Russia (Diplopoda, Polydesmida, Trichopolydesmidae) // Russian Entomological Journal. Vol.24. No.1. P.1-6.

Golovatch S.I., Evsyukov A.P., Reip H. 2016. The millipede family Polydesmidae in the Caucasus (Diplopoda: Polydesmida) // Zootaxa. Vol.4085. No.1. P.1-51.

Short M. 2015. New records of Lophoproctus coecus Pocock, 1894 (Diplopoda, Polyxenida, Lophoproctidae) extend the range of the genus Lophoproctus // ZooKeys. Vol.510. P.209-222. doi:10.3897/zookeys.510.8668

Turbanov I.S., Palatov D.M., Golovatch S.I. 2016. [The state of the art of biospeleology in Russia and other countries of the former Soviet Union: A review of cave (endogean) invertebrate fauna. 2. Arachnida - Acknowledgements] // Zoologicheskii Zhurnal. Vol.95. No.11. P.1283-1304 [in Russian; English translation: Entomological Review 2016, vol.96, no.9, p.1297-1333]. doi.org/10.7868/S0044513416110064

Responsible editor K.G. Mikhailov 